\title{
Changes in Physicochemical Characteristics and Microbiological Quality of Bakery Shortening Formulated with Shea Butter and Fluted Pumpkin Seed Oil During Storage
}

\author{
Kiin-Kabari David Barine*, Eke-Ejiofor Joy, Chibor Bariwere Samuel \\ Department of Food Science and Technology, Rivers State University, Port Harcourt, Nigeria \\ Email address: \\ kabaridavid@yahoo.com (Kiin-Kabari D. B.) \\ ${ }^{*}$ Corresponding author
}

To cite this article:

Kiin-Kabari David Barine, Eke-Ejiofor Joy, Chibor Bariwere Samuel. Changes in Physicochemical Characteristics and Microbiological Quality of Bakery Shortening Formulated with Shea Butter and Fluted Pumpkin Seed Oil During Storage. International Journal of Food Science and Biotechnology. Vol. 3, No. 3, 2018, pp. 89-94. doi: 10.11648/j.ijfsb.20180303.13

Received: June 28, 2018; Accepted: July 11, 2018; Published: October 12, 2018

\begin{abstract}
The objective of this work was to evaluate the changes that occur in physicochemical characteristics and microbiological qualityof bakery shortening formulated with Shea stearin and fluted pumpkin seed oil blends during storage, so as to ascertain its storage stability. Edible oils were extracted from Shea nuts (Vitellaria paradoxa Geartner) and Fluted pumpkin (Telfairia occidentalis Hook) seeds. The extracted Shea butter and fluted pumpkin seed oil samples were refined and modified using two methods namely fractionation and chemical interesterification to produce bakery fats. The Shea butter was fractionated, and the solid stearin fraction blended with fluted pumpkin seed oil in the following ratios: 30:70, 40:60, and 50:50, (Shea stearin: fluted pump seed oil), The blends were stabilized with recommended additives such as; distilled monoglyceride (E471) and preservatives such as; citric acid (E330), BHT (E321), and sodium benzoate (E211), homogenized by continuous stirring and plasticized by chilling to $17^{\circ} \mathrm{C}$, then tempered at $23-25^{\circ} \mathrm{C}$ for $48 \mathrm{~h}$, to attain a stable polymorphic form, used as fractionated blends (FRBs). Another set of 30:70; 40:60; and 50:50 (Shea stearin: fluted pumpkin seed oil), were chemically interesterified with sodium methoxide $\left(\mathrm{CH}_{3} \mathrm{ONa}\right)$ as catalyst, crystalized, stabilized, and used as chemically interesterified fractionated blends (CIEFBs). The products were packed and sealed in opaque plastic cups and stored at room temperature $\left(28 \pm 2^{\circ} \mathrm{C}\right)$ for 90 days. Changes in physicochemical properties (including solid fat content) and microbiological quality (yeast and moulds count) were determined. Peroxide value (PV) and acid value (AV) of the bakery fats formulated with fractionated blends increased slightly after 90 days of storage. There were no significant $(\mathrm{P}>0.05)$ increase in $\mathrm{PV}$ of the interesterified samples after storage for 90 days. No significant change was recorded in the iodine value, slip melting point, and smoke point of the products on storage, except the 30:70 fractionated blend which reduces in iodine value (IV) and smoke point from $94.60 \mathrm{~g} / 100 \mathrm{~g}$ to $92.50 \mathrm{~g} / 100 \mathrm{~g}$, and $200.30^{\circ} \mathrm{C}-198.00^{\circ} \mathrm{C}$, respectively. The products were microbiologically stable throughout the period of storage.
\end{abstract}

Keywords: Physicochemical, Microbiological, Bakery Shortening, Shea Butter, Fluted Pumpkin, Storage

\section{Introduction}

Bakery shortenings are tailored fat systems, whose nutritional and functional properties have been modified in order to deliver specific functional needs; as tenderizing agents, facilitate aeration, texture, mouthfeel, carry flavours and colours, provide a heating medium, and structural integrity to pies, breads, pasta and other bakery products [1]. This modification processes affects the physicochemical characteristics of the fat blends, hence impacting desirable consistency and keeping quality on the end product. Modification of original fats by means of direct blending with other fats, fractionation, hydrogenation and interesterification has been attempted to improve the fat 
functionalities and thus optimize their application in food products [2]. Melting point of $36.57^{\circ} \mathrm{C}$ for Shea butter and $18.65^{\circ} \mathrm{C}$ for fluted pumpkin seed oil with $62.40 \%$ linoleic acid reported earlier by [3] showed that Shea butter will provide a good solid base while fluted pumpkin seed oil will provide the needed plasticity, spreadability and enhanced nutritional value of the products [3]. The quality of shortening is governed by five basic factors, these includes; processing conditions, triacylglycerols and emulsifier composition, tempering conditions, usage temperature and storage conditions [4]. The low melting fat fractions in shortening might liquefy on prolonged storage at high temperatures, and will further solidify on cooling to less functional crystal forms. Solid shortening does not require refrigeration during storage; they however need to be stored away from odour-generating materials, and in a cool, dry place [2]. Attaining a stable crystal structure is an important consideration in the composition of solid shortening, to impact optimum creaming ability and for its ability to incorporate air into dough or cake batter. Shortening must be stable and in the best form and characterized as being smooth and creamy [4]. These properties can be adversely affected by improper and non-uniform storage conditions. Thus, the aim of this study was to access the changes in physicochemical properties and microbiological quality of bakery fats produced from Shea butter and fluted pumpkin seed oil blend, during storage, so as to ascertain its shelve stability.

\section{Materials and Methods}

Healthy nuts of the Shea tree (Vitellaria paradoxa) were procured from Minna, Niger State, while mature, freshly harvested fluted pumpkin fruits (Telfairia occidentalis Hook) were purchased from Bori market in Rivers State, all in Nigeria. The nuts and seeds were cracked/dehulled then oven dried $\left(60^{\circ} \mathrm{C}, 24 \mathrm{~h}\right)$ separately in a hot air oven, milled into flour and oil extracted, using the procedure described earlier by Chibor et al. [3].

\subsection{Oil Refining}

The extracted oil was refined using the procedure described by O'Brien [4]. The crude oil was heated with $8 \%$ $\mathrm{NaOH}_{(\mathrm{aq})}$ for 10 min with continuous stirring, using a laboratory stirrer (model JKL 2145, REMI Motors, India). The treatment was then washed with warm distilled water and the aqueous phase separated using a separatory funnel. The oil was then dried and bleached using 3\% fuller's earth, with continuous stirring at $80^{\circ} \mathrm{C}$ for $20 \mathrm{~min}$. It was filtered at $50^{\circ} \mathrm{C}$ using Whatman no 4 filter paper.

\subsection{Fractionation}

The Shea nut oil was fractionated separately by dry fractionation method, to obtain liquid, and hard stock, using the method describe by ISEO [5]. The oil was heated to $60^{\circ} \mathrm{C}$, then gradually crystallized and separated while cooling to $25^{\circ} \mathrm{C}$.

The hard stock (solid stearin fraction from Shea butter) and the liquid fluted pumpkin seed oil (SS: FPSO) were blended in the ratio: 30:70, 40:60, and 50:50. Each was heated to $70^{\circ} \mathrm{C}$, homogenized with recommended additives such as: Distilled monoglyceride (E471, 0.4\%), citric acid (E330, 0.17\%), Butylated hydroxytoluen (E321, 0.075\%), xanthan gum (E415, 0.2\%), and sodium benzoate (E211, $0.08 \%$ ) [20] [21], crystalized to $17^{\circ} \mathrm{C}$ with continuous stirring, using a laboratory stirrer (model JKL 2145, REMI Motors, India) at 300rpm.

The crystalized blend was tempered at $23-25^{\circ} \mathrm{C}$ for $48 \mathrm{~h}$ [18], then stored in an opaque, sealed plastic cup at room temperature $\left(28 \pm 2^{\circ} \mathrm{C}\right)$, and used as bakery shortenings from fractionated (FRB) blends.

\subsection{Chemical Interesterification}

The hard stock (Shea stearin) and the liquid fluted pumpkin seed oil were first blended at the same ratio of: 30:70, 40:60 and 50:50, then interesterified using the method describe by Alejandro and Ghazani [6]. Sodium Methoxide $\left(\mathrm{CH}_{3} \mathrm{ONa}\right)$ powder was used as catalyst. To $300 \mathrm{~g}$ of fat was added $0.3 \mathrm{~g}$ of $\mathrm{CH}_{3} \mathrm{ONa}$ powder, stirred at $85^{\circ} \mathrm{C}$ for $50 \mathrm{~min}$ and the reaction was stopped with acidic water $(4 \%$ citric acid), and the blend washed with dilute basic water $(0.1 \mathrm{~N}$ $\mathrm{NaOH})(1: 8)$, three $(3 \mathrm{~g})$ of bleaching earth was added, stirred thoroughly and filtered through whatman no 4 filter paper. The blends were washed with warm water, and dried. They were further homogenized with recommended additives, stored and used as bakery shortenings from interesterified fractionated blends (IEFB).

\subsection{Changes in Physicochemical Properties}

Physicochemical properties such as slip melting point (SMP), smoke point (SP), refractive index, acid value (AV), iodine value (IV) and peroxide value (PV) were determined by the method of AOAC [7], at 10 days' interval (from day zero to 90 ).

\subsection{Solid Fat Content}

The solid fat content-temperature profile was determined using the density method, as noted by Nazaruddin [8].

Density of solid fat is higher than the density of liquid oil, so density increase when fat crystalizes and decrease when it melts.

The glass pycnometer was used to measure density at the following temperature: $10^{\circ} \mathrm{C}, 20^{\circ} \mathrm{C}, 30^{\circ} \mathrm{C}, 40^{\circ} \mathrm{C}, 50^{\circ} \mathrm{C}$, and $60^{\circ} \mathrm{C}$. The percentage SFC was calculated using the McClement [9] equation as follows:

$$
\operatorname{SFC}(\%)=\frac{\rho-\rho l}{\rho s-\rho l} \times \frac{100}{1}
$$

$p=$ density of fat at the desired temperature

$\mathrm{pl}=$ density of fat when completely liquid.

$p_{s}=$ density of fat when completely solid. 


\subsection{Microbiological Studies}

The microbiological changes that occurred in the products during storage at room temperature $\left(28 \pm 2^{0} \mathrm{C}\right)$ were studied via moulds and yeast count, using the spread-plate techniquewith potato dextrose agar (PDA) as culture media, incubated at $35^{\circ} \mathrm{C}$ for $72 \mathrm{hr}$, according to the method reported by Fernande et al. [10]. Considering the concentration and physical nature of the continuous lipid phase of bakery shortenings, with greater proportion of crystallized fats, bacterial count was not determined.

\subsection{Statistical Analysis}

All the analyses were carried out in triplicate. Data obtained were subjected to Analysis of variance (ANOVA), differences between means were evaluated using Tukey's multiple comparison test, and significance accepted at $\mathrm{P} \leq$ 0.05 level. The statistical package in Minitab 16 computer program was used.

\section{Results and Discussion}

\subsection{Changes in Physical Properties of Bakery Shortenings during Storage}

As shown in Table 1, there were significant increase in the slip melting point (SMP) of the fractionated blends (FRB1,
FRB2, FRB3) from $36.33^{\circ} \mathrm{C}-39.00^{\circ} \mathrm{C}, 42.67^{\circ} \mathrm{C}-44.00^{\circ} \mathrm{C}$ and $44.33^{\circ} \mathrm{C}-46.00^{\circ} \mathrm{C}$, respectively. The change in melting point of shortening during storage is probably due to polymorphic changes, as the fat molecules realign in order to attain a stable crystalline form. This view was also supported by O'Brien [4] and Ghotra et al., [11]. There was no significant increase $(\mathrm{P}>0.05)$ in the slip melting point of the interesterified fractionated blends.

The smoke point (SP) of fractionated blend (FRB1) reduced significantly $(\mathrm{P}<0.05)$ from $200.30^{\circ} \mathrm{C}$ to $198.00^{\circ} \mathrm{C}$ after 90days of storage. This was likely due to the significant increase in peroxide value (PV) and acid value (AV) of this blend, as smoke point of fats had been shown to reduce with the presence of free fatty acids and other products of fat oxidation [4, 12]. Slight reduction in smoke point were observed in fractionated blends (FRB2 and FRB3), these were however not significant.

The reduction in refractive index $(\mathrm{RI})$ from $1.461-1.460$ in the fractionated blends (FRB), and the interesterified blend (IEFB), after 90 days of storage were not significant $(\mathrm{P}>0.05)$, this was also due to relative stability of the iodine value of these products during storage. Agarwal et al. [13] also reported consistency in RI of shortening after 12 months of storage. The stability of RI during storage is an indication that the unsaturated fats in the products did not reduce significantly during the period of storage [14].

Table 1. Changes in the Slip Melting Point, Smoke Point and Refractive Index of Bakery Shortenings Formulated with Shea Stearin and Fluted Pumpkin Seed Oil Blends during Storage.

\begin{tabular}{|c|c|c|c|c|c|c|c|c|c|c|c|}
\hline \multirow{2}{*}{ Parameter } & \multirow{2}{*}{ Fat Samples } & \multicolumn{10}{|c|}{ STORAGE TIME (DAYS) } \\
\hline & & $\mathbf{0}$ & 10 & 20 & 30 & 40 & $\mathbf{5 0}$ & 60 & 70 & 80 & 90 \\
\hline \multirow[t]{6}{*}{$\operatorname{SMP}\left({ }^{\circ} \mathrm{C}\right)$} & FRB1 & $36.33^{\mathrm{c}}$ & $36.30^{\mathrm{c}}$ & $36.67^{\mathrm{c}}$ & $36.67^{\mathrm{c}}$ & $36.67^{\mathrm{c}}$ & $37.33^{\mathrm{bc}}$ & $38.30^{\mathrm{ab}}$ & $38.70^{\mathrm{ab}}$ & $38.70^{\mathrm{ab}}$ & $39,00^{\mathrm{a}}$ \\
\hline & FRB2 & $42.67^{b}$ & $42.70^{\mathrm{b}}$ & $43.00^{\mathrm{b}}$ & $43.00^{\mathrm{b}}$ & $43.33^{\mathrm{ab}}$ & $43.33^{\mathrm{ab}}$ & $43.70^{\mathrm{a}}$ & $43.70^{\mathrm{a}}$ & $43.70^{\mathrm{a}}$ & $44.00^{\mathrm{a}}$ \\
\hline & FRB3 & $44.33^{\mathrm{b}}$ & $44.30^{\mathrm{b}}$ & $44.67^{\mathrm{b}}$ & $44.67^{\mathrm{b}}$ & $44.67^{\mathrm{b}}$ & $45.00^{\mathrm{ab}}$ & $45.30^{\mathrm{ab}}$ & $46.00^{\mathrm{a}}$ & $46.00^{\mathrm{a}}$ & $46.00^{\mathrm{a}}$ \\
\hline & IEFB1 & $34.33^{\mathrm{a}}$ & $34.70^{\mathrm{a}}$ & $35.00^{\mathrm{a}}$ & $35.00^{\mathrm{a}}$ & $35.00^{\mathrm{a}}$ & $35.33^{\mathrm{a}}$ & $35.30^{\mathrm{a}}$ & $35.70^{\mathrm{a}}$ & $35.70^{\mathrm{a}}$ & $35.70^{\mathrm{a}}$ \\
\hline & IEFB2 & $36.33^{\mathrm{a}}$ & $36.30^{\mathrm{a}}$ & $36.67^{\mathrm{a}}$ & $36.67^{\mathrm{a}}$ & $36.67^{\mathrm{a}}$ & $36.67^{\mathrm{a}}$ & $36.70^{\mathrm{a}}$ & $37.00^{\mathrm{a}}$ & $37.00^{\mathrm{a}}$ & $37.00^{\mathrm{a}}$ \\
\hline & IEFB3 & $39.67^{\mathrm{a}}$ & $39.70^{\mathrm{a}}$ & $39.67^{\mathrm{a}}$ & $39.67^{\mathrm{a}}$ & $40.00^{\mathrm{a}}$ & $40.00^{\mathrm{a}}$ & $40.30^{\mathrm{a}}$ & $40.30^{\mathrm{a}}$ & $40.70^{\mathrm{a}}$ & $40.70^{\mathrm{a}}$ \\
\hline \multirow[t]{6}{*}{$\mathrm{SP}\left({ }^{\circ} \mathrm{C}\right)$} & FRB1 & $200.3^{\mathrm{ab}}$ & $201.0^{\mathrm{a}}$ & $200.5^{\mathrm{ab}}$ & $200.5^{\mathrm{ab}}$ & $200.0^{\mathrm{ab}}$ & $199.5^{\mathrm{ab}}$ & $199.0^{\mathrm{ab}}$ & $199.0^{\mathrm{ab}}$ & $198.0^{\mathrm{b}}$ & $198.0^{\mathrm{b}}$ \\
\hline & FRB2 & $199.0^{\mathrm{a}}$ & $199.0^{\mathrm{a}}$ & $198.5^{\mathrm{a}}$ & $197.5^{\mathrm{a}}$ & $198.0^{\mathrm{a}}$ & $197.5^{\mathrm{a}}$ & $198.0^{\mathrm{a}}$ & $197.5^{\mathrm{a}}$ & $197.0^{\mathrm{a}}$ & $197.0^{\mathrm{a}}$ \\
\hline & FRB3 & $199.0^{\mathrm{a}}$ & $199.0^{\mathrm{a}}$ & $198.5^{\mathrm{a}}$ & $198.0^{\mathrm{a}}$ & $197.5^{\mathrm{a}}$ & $197.0^{\mathrm{a}}$ & $197.0^{\mathrm{a}}$ & $197.0^{\mathrm{a}}$ & $197.0^{\mathrm{a}}$ & $197.0^{\mathrm{a}}$ \\
\hline & IEFB1 & $202.0^{\mathrm{a}}$ & $202.0^{\mathrm{a}}$ & $202.0^{\mathrm{a}}$ & $202.0^{\mathrm{a}}$ & $202.0^{\mathrm{a}}$ & $202.0^{\mathrm{a}}$ & $201.5^{\mathrm{a}}$ & $202.0^{\mathrm{a}}$ & $201.5^{\mathrm{a}}$ & $201.0^{\mathrm{a}}$ \\
\hline & IEFB2 & $202.3^{\mathrm{a}}$ & $202.0^{\mathrm{a}}$ & $202.5^{\mathrm{a}}$ & $202.5^{\mathrm{a}}$ & $202.0^{\mathrm{a}}$ & $202.0^{\mathrm{a}}$ & $202.0^{\mathrm{a}}$ & $202.0^{\mathrm{a}}$ & $201.5^{\mathrm{a}}$ & $201.5^{\mathrm{a}}$ \\
\hline & IEFB3 & $201.7^{\mathrm{a}}$ & $202.0^{\mathrm{a}}$ & $201.5^{\mathrm{a}}$ & $201.5^{\mathrm{a}}$ & $201.5^{\mathrm{a}}$ & $201.5^{\mathrm{a}}$ & $201.0^{\mathrm{a}}$ & $201.0^{\mathrm{a}}$ & $201.5^{\mathrm{a}}$ & $201.0^{\mathrm{a}}$ \\
\hline \multirow[t]{6}{*}{ RI } & FRB1 & $1.461^{\mathrm{a}}$ & $1.460^{\mathrm{a}}$ & $1.461^{\mathrm{a}}$ & $1.461^{\mathrm{a}}$ & $1.461^{\mathrm{a}}$ & $1.461^{\mathrm{a}}$ & $1.460^{\mathrm{a}}$ & $1.460^{\mathrm{a}}$ & $1.460^{\mathrm{a}}$ & $1.460^{\mathrm{a}}$ \\
\hline & FRB2 & $1.460^{\mathrm{a}}$ & $1.460^{\mathrm{a}}$ & $1.461^{\mathrm{a}}$ & $1.460^{\mathrm{a}}$ & $1.460^{\mathrm{a}}$ & $1.461^{\mathrm{a}}$ & $1.460^{\mathrm{a}}$ & $1.460^{\mathrm{a}}$ & $1.460^{\mathrm{a}}$ & $1.460^{\mathrm{a}}$ \\
\hline & FRB3 & $1.460^{\mathrm{a}}$ & $1.460^{\mathrm{a}}$ & $1.460^{\mathrm{a}}$ & $1.460^{\mathrm{a}}$ & $1.460^{\mathrm{a}}$ & $1.459^{\mathrm{a}}$ & $1.459^{\mathrm{a}}$ & $1.460^{\mathrm{a}}$ & $1.459^{\mathrm{a}}$ & $1.459^{\mathrm{a}}$ \\
\hline & IEFB 1 & $1.461^{\mathrm{a}}$ & $1.460^{\mathrm{a}}$ & $1.461^{\mathrm{a}}$ & $1.462^{\mathrm{a}}$ & $1.462^{\mathrm{a}}$ & $1.461^{\mathrm{a}}$ & $1.460^{\mathrm{a}}$ & $1.460^{\mathrm{a}}$ & $1.460^{\mathrm{a}}$ & $1.460^{\mathrm{a}}$ \\
\hline & IEFB2 & $1.461^{\mathrm{a}}$ & $1.460^{\mathrm{a}}$ & $1.461^{\mathrm{a}}$ & $1.460^{\mathrm{a}}$ & $1.461^{\mathrm{a}}$ & $1.460^{\mathrm{a}}$ & $1.460^{\mathrm{a}}$ & $1.460^{\mathrm{a}}$ & $1.460^{\mathrm{a}}$ & $1.460^{\mathrm{a}}$ \\
\hline & IEFB3 & $1.460^{\mathrm{a}}$ & $1.460^{\mathrm{a}}$ & $1.460^{\mathrm{a}}$ & $1.460^{\mathrm{a}}$ & $1.460^{\mathrm{a}}$ & $1.460^{\mathrm{a}}$ & $1.460^{\mathrm{a}}$ & $1.460^{\mathrm{a}}$ & $1.459^{\mathrm{a}}$ & $1.459^{\mathrm{a}}$ \\
\hline
\end{tabular}

Mean values bearing the same superscript in the same row do not differ significantly $(\mathrm{P}>0.05)$. Values are means of duplicate samples.

Key:

$\mathrm{SMP}=$ slip melting point; $\mathrm{SP}=$ smoke point; $\mathrm{RI}=$ refractive index

FRB1 $=$ fractionated blend of 30:70 (Shea stearin: fluted pumpkin seed oil)

FRB2 $=$ fractionated blend of 40:60 (Shea stearin: fluted pumpkin seed oil)

FRB3 $=$ fractionated blend of 50:50 (Shea stearin: fluted pumpkin seed oil)

IEFB1 = interesterified fractionated blend of 30:70 (Shea stearin: fluted pumpkin seed oil)

IEFB2 $=$ interesterified fractionated blend of 40:60 (Shea stearin: fluted pumpkin seed oil)

IEFB3 = interesterified fractionated blend of 50:50 (Shea stearin: fluted pumpkin seed oil) 
The solid fat content (SFC) of bakery shortenings formulated with fractionated blends of Shea stearin and fluted pumpkin seed oil increased significantly $(\mathrm{P}<0.05)$ after 90 days of storage, as shown in figures 1 and 2 . Fractionated blends of 30: 70 (FRB1), 40: 60 (FRB2) and 50: 50 (FRB3) Shea stearin: fluted pumpkin seed oil showed changes in SFC from $20.00 \%-22.30 \%, 31.33 \%-34.00 \%$, and $36.33 \%$ $48.33 \%$, respectively, at $30^{\circ} \mathrm{C}$ after 90 days of storage. The solid fat content of bakery shortenings formulated with interesterified fractionated blends of Shea stearin and fluted pumpkin seed oil were relatively stable, with no significant ( $\mathrm{P}>0.05)$ change in SFC during storage. Ghazalia et al. [15] also reported increase in SFC of vegetable shortening from $14.8 \%$ to $22.9 \%$ for a storage period of 12 weeks at $30^{\circ} \mathrm{C}$, and $22.5 \%$ to $37.5 \%$ at $20^{\circ} \mathrm{C}$.

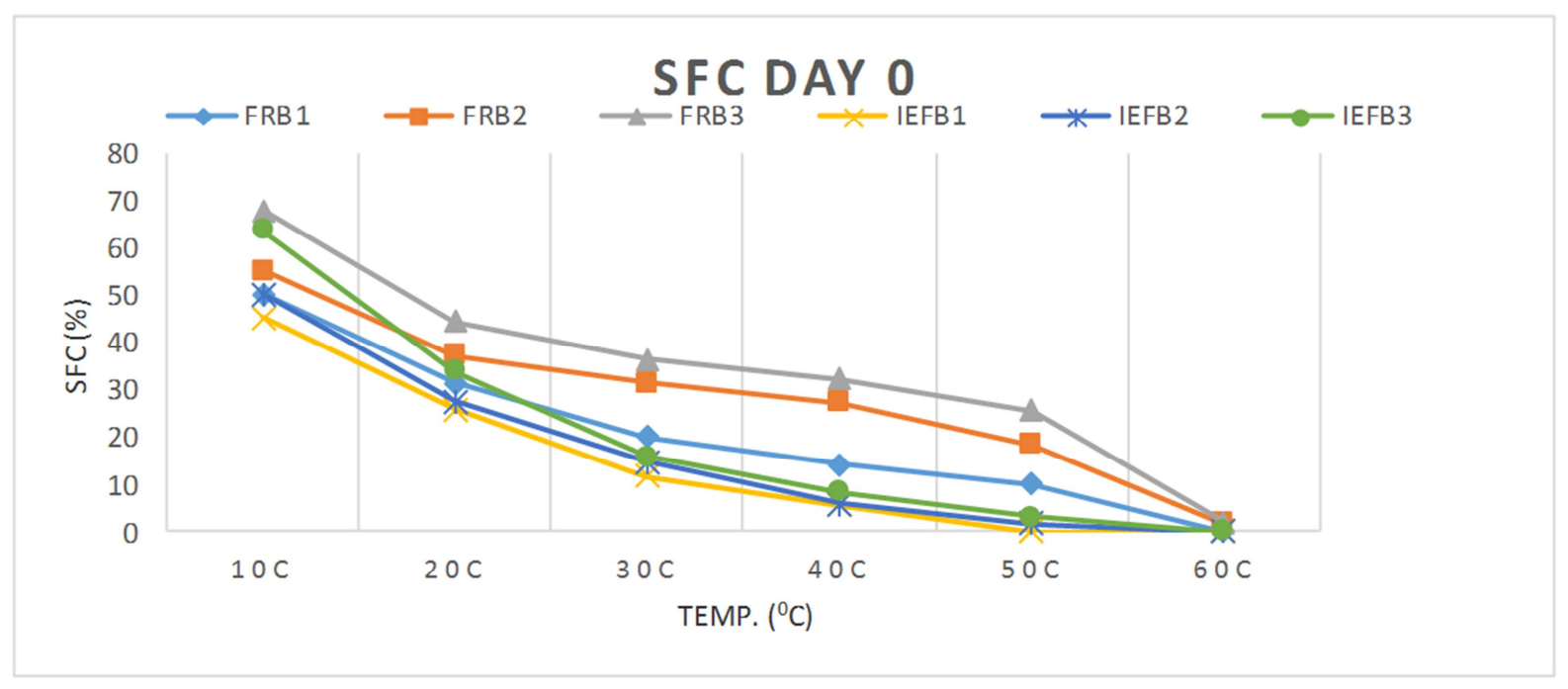

Figure 1. Solid Fat Content - Temperature Profile of the Bakery Fat Samples Stored for Zero Day.

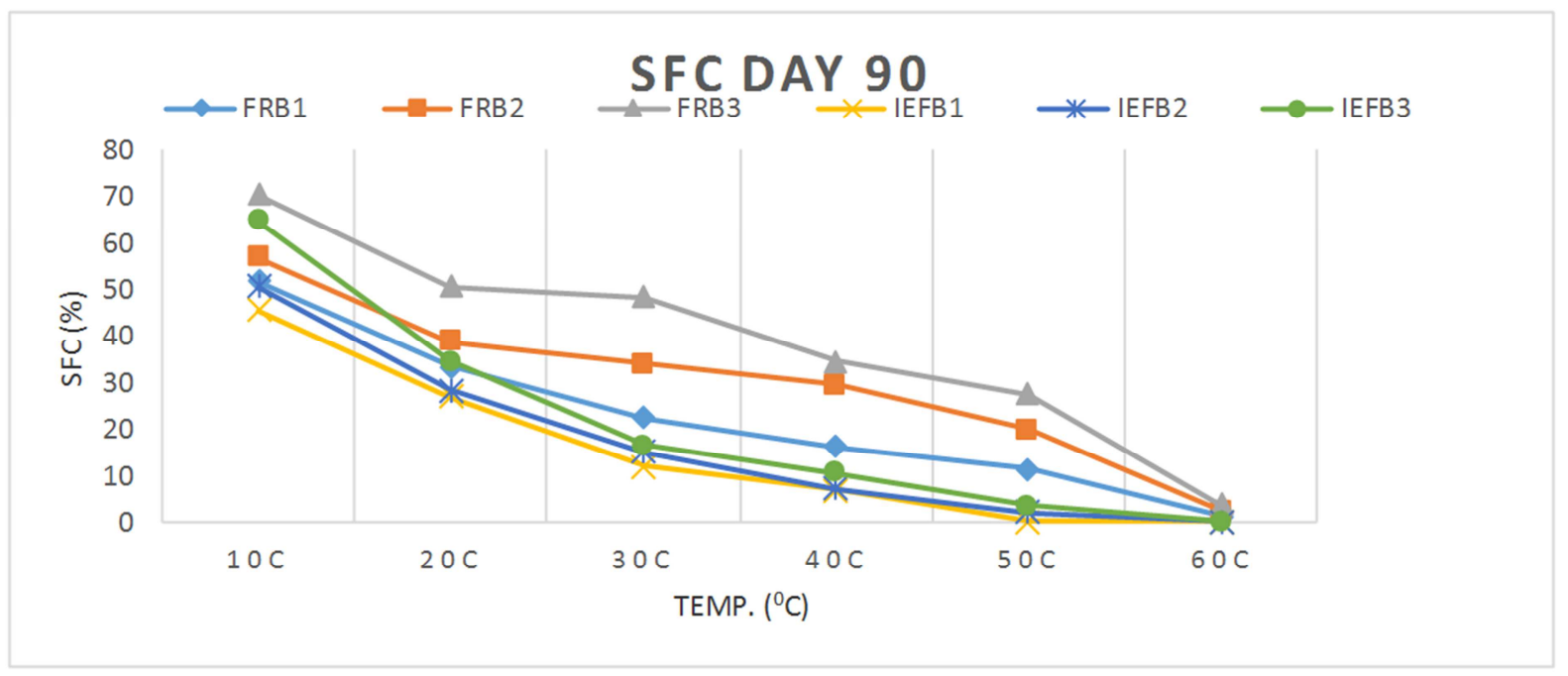

Figure 2. Solid Fat Content - Temperature Profile of the Bakery Fat Samples Stored for 90 Days.

\subsection{Changes in Chemical Properties of Bakery Shortenings during Storage}

\subsubsection{Iodine Value (IV)}

Iodine value is an index of the unsaturation, which is the most important analytical characteristic of oil. Data on changes in the iodine value of the bakery shortenings during storage is presented in Table 2. The iodine value (IV) of the fractionated blend (FRB1), dropped from $94.60 \mathrm{~g} / 100 \mathrm{~g}$ to $92.50 \mathrm{~g} / 100 \mathrm{~g}$ after 90 days of storage. There was no significant change $(\mathrm{P}>0.05)$ in IV of the interesterified bakery fat samples during the storage period. Gulla and
Waghray [2] also reported reduction in IV from $92.4 \mathrm{~g} / 100 \mathrm{~g}$ to $90.6 \mathrm{~g} / 100 \mathrm{~g}$ for a blend of sesame oil/rice bran oil $(80: 20)$ stored for 12 months. During the end of storage period, slight change in iodine value observed might be due to termination stage of auto oxidation reaction [16].

\subsubsection{Acid Value (AV)}

The acid values (AV) of the products were constant up to day 20 , but increased gradually to day 90 (Table 3 ). The highest AV given after 90 days of storage was $0.140 \mathrm{mgKOH} / \mathrm{g}$ for fractionated blend of ratio 50:50 (FRB3), this was significantly lower than the maximum acceptable value of 
$0.6 \mathrm{mgKOH} / \mathrm{g}$ for edible oil/fats (NIS:289, 1992) and also lower than the maximum acceptable value of $0.3 \mathrm{mgKOH} / \mathrm{g}$ for margarine/shortenings [14]. Low acid value in fat indicates that the shortening will be stable over a long period of time and protect against rancidity and peroxidation [17].

\subsubsection{Peroxide Value (PV)}

Table 4. gave the changes in peroxide value of the bakery shortenings during a 90 days' storage period at room temperature $\left(28 \pm 2^{\circ} \mathrm{C}\right)$. Peroxide value (PV) of the fractionated blends (FRBs) were relatively constant up to day 20 , but increased significantly $(\mathrm{p}<0.05)$ at day 90 . There was no significant $(p>0.05)$ increase in the PV of the interesterified blends. This showed that the interesterified samples exhibits better oxidative stability. This observation was supported by O'Brien [4]. The PV of all the samples fall below the maximum National acceptable PV of $2.00 \mathrm{mEq} / \mathrm{kg}$ for shortenings [14], indicating that the products were stable during a 90 days' storage period. Gulla and Waghray [2] reported increase in $\mathrm{PV}$ from $3.65 \mathrm{mEqO} 2 / \mathrm{kg}$ to $14.7 \mathrm{mEqO} 2 / \mathrm{kg}$ for a $(80: 20)$ blend of sesame oil and rice bran oil stored for 12 months.

Table 2. Changes in Iodine value (g/100g) of Bakery Shortenings Formulated with Shea Stearin and Fluted Pumpkin Seed Oil Blends during Storage.

\begin{tabular}{|c|c|c|c|c|c|c|c|c|c|c|}
\hline FAT & DAYS & & & & & & & & & \\
\hline SAMPLES & 0 & 10 & 20 & 30 & 40 & 50 & 60 & 70 & 80 & 90 \\
\hline FRB1 & $94.62^{\mathrm{a}}$ & $94.60^{\mathrm{a}}$ & $94.62^{\mathrm{a}}$ & $94.41^{\mathrm{ab}}$ & $94.41^{\mathrm{a}}$ & $94.41^{\mathrm{a}}$ & $93.80^{\mathrm{b}}$ & $93.80^{\mathrm{b}}$ & $92.50^{c}$ & $92.50^{\mathrm{c}}$ \\
\hline FRB2 & $92.30^{\mathrm{a}}$ & $92.30^{\mathrm{a}}$ & $92.30^{\mathrm{a}}$ & $92.30^{\mathrm{a}}$ & $92.16^{\mathrm{a}}$ & $92.16^{\mathrm{a}}$ & $92.16^{\mathrm{a}}$ & $92.10^{\mathrm{a}}$ & $92.10^{\mathrm{a}}$ & $92.10^{\mathrm{a}}$ \\
\hline FRB3 & $88.92^{\mathrm{a}}$ & $88.92^{\mathrm{a}}$ & $88.90^{\mathrm{a}}$ & $88.92^{\mathrm{a}}$ & $88.92^{\mathrm{a}}$ & $88.90^{\mathrm{a}}$ & $88.81^{\mathrm{a}}$ & $88.81^{\mathrm{a}}$ & $88.81^{\mathrm{a}}$ & $88.81^{\mathrm{a}}$ \\
\hline IEFB1 & $93.78^{\mathrm{a}}$ & $93.80^{\mathrm{a}}$ & $93.78^{\mathrm{a}}$ & $93.78^{\mathrm{a}}$ & $93.78^{\mathrm{a}}$ & $93.52^{\mathrm{a}}$ & $93.50^{\mathrm{a}}$ & $93.50^{\mathrm{a}}$ & $93.50^{\mathrm{a}}$ & $93.50^{\mathrm{a}}$ \\
\hline IEFB2 & $92.62^{\mathrm{a}}$ & $92.62^{\mathrm{a}}$ & $92.60^{\mathrm{a}}$ & $92.60^{\mathrm{a}}$ & $92.62^{\mathrm{a}}$ & $92.60^{\mathrm{a}}$ & $92.60^{\mathrm{a}}$ & $92.58^{\mathrm{a}}$ & $92.58^{\mathrm{a}}$ & $92.58^{\mathrm{a}}$ \\
\hline IEFB3 & $89.28^{\mathrm{a}}$ & $89.28^{\mathrm{a}}$ & $89.28^{\mathrm{a}}$ & $89.24^{\mathrm{a}}$ & $89.28^{\mathrm{a}}$ & $89.24^{\mathrm{a}}$ & $89.24^{\mathrm{a}}$ & $89.20^{\mathrm{a}}$ & $89.20^{\mathrm{a}}$ & $89.20^{\mathrm{a}}$ \\
\hline
\end{tabular}

Mean values bearing the same superscript in the same row do not differ significantly $(\mathrm{P}>0.05)$. Values are means of duplicate samples.

Table 3. Changes in Acid Value (mgKOH/g) Of Bakery Shortenings Formulated with Shea Stearin and Fluted Pumpkin Seed Oil Blends during Storage.

\begin{tabular}{|c|c|c|c|c|c|c|c|c|c|c|}
\hline FAT & (DAYS) & & & & & & & & & \\
\hline BLEND & 0 & 10 & 20 & 30 & 40 & 50 & 60 & 70 & 80 & 90 \\
\hline FRB1 & $0.035^{\mathrm{c}}$ & $0.040^{\mathrm{c}}$ & $0.042^{c}$ & $0.056^{\mathrm{bc}}$ & $0.070^{\mathrm{ab}}$ & $0.070^{\mathrm{ab}}$ & $0.070^{\mathrm{ab}}$ & $0.080^{\mathrm{a}}$ & $0.080^{\mathrm{a}}$ & $0.080^{\mathrm{a}}$ \\
\hline FRB2 & $0.047^{\mathrm{c}}$ & $0.050^{\mathrm{bc}}$ & $0.047^{\mathrm{bc}}$ & $0.056^{\mathrm{bc}}$ & $0.070^{\mathrm{abc}}$ & $0.084^{\mathrm{ab}}$ & $0.080^{\mathrm{abc}}$ & $0.080^{\mathrm{abc}}$ & $0.100^{\mathrm{a}}$ & $0.100^{\mathrm{a}}$ \\
\hline FRB3 & $0.103^{\mathrm{a}}$ & $0.100^{\mathrm{a}}$ & $0.112^{\mathrm{a}}$ & $0.112^{\mathrm{a}}$ & $0.112^{\mathrm{a}}$ & $0.126^{\mathrm{a}}$ & $0.130^{\mathrm{a}}$ & $0.130^{\mathrm{a}}$ & $0.140^{\mathrm{a}}$ & $0.140^{\mathrm{a}}$ \\
\hline IEFB1 & $0.028^{\mathrm{c}}$ & $0.030^{\mathrm{c}}$ & $0.028^{\mathrm{c}}$ & $0.042^{\mathrm{b}}$ & $0.042^{\mathrm{b}}$ & $0.042^{\mathrm{b}}$ & $0.040^{\mathrm{b}}$ & $0.040^{\mathrm{b}}$ & $0.040^{\mathrm{b}}$ & $0.060^{\mathrm{a}}$ \\
\hline IEFB2 & $0.037^{b}$ & $0.040^{\mathrm{b}}$ & $0.042^{\mathrm{b}}$ & $0.042^{\mathrm{b}}$ & $0.042^{\mathrm{b}}$ & $0.042^{\mathrm{b}}$ & $0.060^{\mathrm{ab}}$ & $0.060^{\mathrm{ab}}$ & $0.060^{\mathrm{ab}}$ & $0.070^{\mathrm{a}}$ \\
\hline IEFB3 & $0.047^{\mathrm{a}}$ & $0.050^{\mathrm{a}}$ & $0.047^{\mathrm{a}}$ & $0.047^{\mathrm{a}}$ & $0.056^{\mathrm{a}}$ & $0.056^{\mathrm{a}}$ & $0.060^{\mathrm{a}}$ & $0.060^{\mathrm{a}}$ & $0.060^{\mathrm{a}}$ & $0.070^{\mathrm{a}}$ \\
\hline
\end{tabular}

Mean values bearing the same superscript in the same row do not differ significantly $(\mathrm{P}>0.05)$. Values are means of duplicate samples.

Table 4. Changes in Peroxide Value ( $\mathrm{mEq} / \mathrm{kg}$ ) Of Bakery Shortenings Formulated with Shea Stearin and Fluted Pumpkin Seed Oil Blends during Storage.

\begin{tabular}{|c|c|c|c|c|c|c|c|c|c|c|}
\hline FAT & TIMI & & & & & & & & & \\
\hline BLEND & 0 & 10 & 20 & 30 & 40 & 50 & 60 & 70 & 80 & 90 \\
\hline FRB1 & $0.73^{\mathrm{c}}$ & $0.77^{\mathrm{bc}}$ & $0.80^{\mathrm{bc}}$ & $0.85^{\mathrm{abc}}$ & $0.87^{\mathrm{abc}}$ & $0.90^{\mathrm{ab}}$ & $0.90^{\mathrm{ab}}$ & $0.90^{\mathrm{ab}}$ & $0.97^{\mathrm{a}}$ & $1.00^{\mathrm{a}}$ \\
\hline FRB2 & $0.70^{\mathrm{a}}$ & $0.70^{\mathrm{a}}$ & $0.75^{\mathrm{a}}$ & $0.75^{\mathrm{a}}$ & $0.85^{\mathrm{a}}$ & $0.85^{\mathrm{a}}$ & $0.90^{\mathrm{a}}$ & $0.90^{\mathrm{a}}$ & $0.90^{\mathrm{a}}$ & $0.93^{\mathrm{a}}$ \\
\hline FRB3 & $0.57^{\mathrm{d}}$ & $0.63^{\text {cd }}$ & $0.70^{\text {bcd }}$ & $0.70^{\text {bcd }}$ & $0.75^{\mathrm{abc}}$ & $0.80^{\mathrm{abc}}$ & $0.80^{\mathrm{abc}}$ & $0.85^{\mathrm{ab}}$ & $0.87^{\mathrm{ab}}$ & $0.90^{\mathrm{a}}$ \\
\hline IEFB1 & $0.70^{\mathrm{a}}$ & $0.70^{\mathrm{a}}$ & $0.70^{\mathrm{a}}$ & $0.70^{\mathrm{a}}$ & $0.70^{\mathrm{a}}$ & $0.70^{\mathrm{a}}$ & $0.70^{\mathrm{a}}$ & $0.70^{\mathrm{a}}$ & $0.75^{\mathrm{a}}$ & $0.75^{\mathrm{a}}$ \\
\hline IEFB2 & $0.67^{\mathrm{a}}$ & $0.65^{\mathrm{a}}$ & $0.65^{\mathrm{a}}$ & $0.65^{\mathrm{a}}$ & $0.70^{\mathrm{a}}$ & $0.70^{\mathrm{a}}$ & $0.70^{\mathrm{a}}$ & $0.70^{\mathrm{a}}$ & $0.70^{\mathrm{a}}$ & $0.75^{\mathrm{a}}$ \\
\hline IEFB3 & $0.57^{\mathrm{a}}$ & $0.60^{\mathrm{a}}$ & $0.60^{\mathrm{a}}$ & $0.60^{\mathrm{a}}$ & $0.60^{\mathrm{a}}$ & $0.60^{\mathrm{a}}$ & $0.60^{\mathrm{a}}$ & $0.60^{\mathrm{a}}$ & $0.60^{\mathrm{a}}$ & $0.65^{\mathrm{a}}$ \\
\hline
\end{tabular}

Mean values bearing the same superscript in the same row do not differ significantly $(\mathrm{P}>0.05)$. Values are means of duplicate samples.

Key:

FRB1 $=$ fractionated blend of 30:70 (Shea stearin: fluted pumpkin seed oil)

FRB2 $=$ fractionated blend of 40:60 (Shea stearin: fluted pumpkin seed oil)

FRB3 $=$ fractionated blend of 50:50 (Shea stearin: fluted pumpkin seed oil)

IEFB1 $=$ interesterified fractionated blend of 30:70 (Shea stearin: fluted pumpkin seed oil)

IEFB2 $=$ interesterified fractionated blend of 40:60 (Shea stearin: fluted pumpkin seed oil)

IEFB3 $=$ interesterified fractionated blend of 50:50 (Shea stearin: fluted pumpkin seed oil)

\subsection{Microbiological Storage Studies}

The colonies of yeast/moulds recorded after 30 days of storage were probably due to the development of their spore or contamination from improper sealing of packaging containers. The counts of $5.0 \times 10^{2} \mathrm{CFU} / \mathrm{ml}$, and $6.0 \times 10^{2}$ $\mathrm{CFU} / \mathrm{ml}$ noticed from FRB1, and IEFB1 after 90 days of storage (Table 5) were below the marginal acceptable count of $5.0 \times 10^{6} \mathrm{CFU} / \mathrm{ml}$, for table spreads and margarine [18]. As supported by Charteris [19], microbiological stability of the fats was due to the concentration and physical nature of the continuous lipid phase, with greater proportion of crystallized fats. Also, by the presence of emulsifiers, stabilizers and preservatives. 
Table 5. Total Plate Counts for Moulds and Yeast in the Bakery Shortenings during Storage.

\begin{tabular}{llll}
\hline TIME & CULTURE & Yeast/Moulds in Samples & \\
\cline { 3 - 4 } (Days) & MEDIA & FRB1 (CFU/ml) & IEFB1 (CFU/ml) \\
\hline 0 & PDA & ND & ND \\
30 & PDA & $1.6 \times 10^{2}$ & $2.0 \times 10^{2}$ \\
60 & PDA & $2.5 \times 10^{2}$ & $2.8 \times 10^{2}$ \\
90 & PDA & $4.1 \times 10^{2}$ & $5.0 \times 10^{2}$ \\
\hline
\end{tabular}

Key:

FRB1 $=$ fractionated blend of 30:70 (Shea stearin: fluted pumpkin seed oil)

IEFB1 = interesterified fractionated blend of 30:70 (Shea stearin: fluted pumpkin seed oil)

$\mathrm{PDA}=$ potato dextrose agar

$\mathrm{ND}=$ not detected

\section{Conclusion}

Findings from the work showed that the melting point, smoke point and refractive index of bakery shortenings formulated with interesterified fractionated blends of 30:70, 40:60 and 50:50 Shea stearin and fluted pumpkin seed oil do not change significantly after 90 days of storage, at $28 \pm 2^{\circ} \mathrm{C}$. The acid value (AV) and peroxide value (PV) of the products were remarkably lower than $0.3 \mathrm{mgKOH} / \mathrm{g}$ and $2.00 \mathrm{mEq} / \mathrm{kg}$, respectively, which are the maximum acceptable values for margarine/shortenings. The bakery shortenings showed desired physicochemical properties for: frying fats, bakery fats, icing-shortening, filler fats and all-purpose shortenings. These characteristics as well as the microbiological quality were remarkably stable after 90 days of storage.

\section{References}

[1] Rios, R. V., Pessanha, M. D. F., Almeida, P. F., Viana, C. L. and Lanne, S. C. (2014). Application of fat in some food products. Food Science and Technology (Campinas), 3(1), 315 .

[2] Gulla, S. and Waghray, K. (2011). Effect of storage on physico-chemical characteristics and fatty acid composition of selected oil blends. Journal of Lipid Science, 3(1), 35-46.

[3] Chibor, B. S., Kiin-Kabari, D. B. and Eke-Ejiofor, J. (2017). Physicochemical properties and fatty acid profile of shea butter and fluted pumpkin seed oil, a suitable blend in bakery fat production. International Journal of Nutrition and Food Science, 6(3), 122-128.

[4] O'Brien, R. D. (2004). Fats and Oil. Formulating and Processing for Application, $2^{\text {nd }}$ ed. Technomic Publishing Co. Inc Lancester, pp.437-458.

[5] Institute of Shortening and Edible Oils (ISEO). (2006). Food Fats and Oil, $9^{\text {th }}$ edition. Washington, DC. Retrieved from http://www.iseo.org. $7^{\text {th }}$ June, 2016.

[6] Alejandro, G. M. and Ghazani S. M, (2012). Trends in Interesterification of Fats and Oil. Retrieved from https://www.ilsina.org. $15^{\text {th }}$ June, 2016.

[7] AOAC (2012). Association of Official Analytical Chemist, Official Methods of Analysis. $19^{\text {th }}$ Edition, Washington, D.C.
[8] Nazaruddin, R. (2013). Determination of SFC in Oils and Fats. Advance Chemical Analysis of Food Laboratory. Retrieved from http://sitiradhiahabrazak.files.wordpress.com. 2nd June, 2016.

[9] McClement, D. J. (1999). Food Emulsions: Principles, Practices and Techniques. Boca Raton, Florida, CRC Press.

[10] Fernande, H., Kashin, H., Akissoe, N., Coulibaly, O., Fandohan, P. and Hounhouigan, J. (2011). Effect of storage conditions on microbiological and physicochemical quality of shea butter. Journal of Food Science and Technology, 48(3), 274-279.

[11] Ghotra, B. S., Dyal, S. D. and Narine, S. S. (2002). Lipid shortenings: a review. Food Research International, 35, 10151048 .

[12] Bockish, M. (1998). Fats and Oils Handbook, Champaign, IL: American Oil Chemists' Society Press.

[13] Agarwal, A., Siddhu, A., Sundararaj, P. and Taneja, K. K. (2000). Storage Stability at Household Level of Edible Grade Crude Palm Oil. Journal of Oil Technology Association of India, 32(3), 124-128.

[14] Zaeroomali, M., Maghsoudlou, Y. and Araey, P. (2014). Effect of storage on margarine in refrigerated temperature. European Journal of Experimental Biology, 4(3), 182-184.

[15] Ghazalia, F., Lai, O. M., Cho, C. and Chong, L. (2000). Physical properties of lipase-catalysed transesterified blends of palm stearin and anhydrous milk fat. Journal of Food Chemistry. 70, 215-219.

[16] Nasirullah, K. N., Ankaiah, M. N., Krishnamurthy, M. N. and Nagaraja, K. V. (1991). Quality characteristics of edible vegetable oil blends. Journal of American Oil Chemists Society, 68, 446-447.

[17] Aremu, M. O., Ibrahim, H., and Bamidele, T. O. (2015). Physicochemical characteristics of the oils extracted from some Nigerian plant foods. Chemical and Process Engineering Research, 32, 22-25.

[18] International Commission on Microbiological Specification for Foods (ICMSF). (1995). Food Administration Manual. Version 2.0. Retrieved from http://www.icmsf.org. 3rd July, 2016).

[19] Charteris, W. P. (1995). Physicochemical aspect of the microbiology of edible table spreads. International Journal of Dairy Technology, 48(3), 87-96. 